\title{
Bifurcation of an ultimate leg in Cryptops parisi Brolemann, 1920 (Chilopoda: Scolopendromorpha: Cryptopidae)
}

\section{Ветвление надвое последней ноги у Cryptops parisi Brolemann, 1920 (Chilopoda: Scolopendromorpha: Cryptopidae)}

\author{
Dalibor Z. Stojanović ${ }^{*}$, Bojan M. Mitić ${ }^{1}$, Slobodan E. Makarov ${ }^{1}$ \\ Аалибор 3. Стојановић ${ }^{1 *}$, Бојан М. Митић ${ }^{1}$, Слободан Е. Макаров ${ }^{1}$
}

\footnotetext{
${ }^{1}$ Institute of Zoology, University of Belgrade - Faculty of Biology, Studentski Trg 16, 11000 Belgrade, Serbia.

1 Университет Белграда, Биологический факультет, Институт зоологии, 11000 Белград, Сербия.

* Corresponding author: dstojanovic@bio.bg.ac.rs
}

KEY WORDS: Chilopoda, Cryptops parisi, schistomely, Serbia.

КЛЮЧЕВЫЕ СЛОВА: Chilopoda, Cryptops parisi, схистомелия, Сербия.

\begin{abstract}
A case of schistomely (= bifurcation) of one ultimate leg in an adult female of the scolopendromorph centipede, Cryptops parisi, is presented. A possible origin of the anomaly observed is discussed. All previously published records of leg bifurcation in centipedes are summarized.

How to cite this article: Stojanović D.Z., Mitić B.M., Makarov S.E. 2019. Bifurcation of an ultimate leg in Cryptops parisi Brolemann, 1920 (Chilopoda: Scolopendromorpha: Cryptopidae) // Arthropoda Selecta. Vol.28. No.1. P.21-25. doi: 10.15298/arthsel. 28.1 .03
\end{abstract}

РЕЗЮМЕ. Представлен случай схистомелии (= ветвления надвое) последней ноги у одной взрослой самки скрорпендроморфы Cryptops parisi. Обсуждается возможное происхождение этой аномалии. Резюмированы все до сих пор отмеченные случаи схистомелии ног у губоногих многоножек.

\section{Introduction}

The oldest published records of abnormal phenotypes in centipedes date from the end of the $19^{\text {th }}$ and early $20^{\text {th }}$ century [Hutton, 1878; Brölemann, 1894, 1904; Gadeau de Kerville, 1898; Léger, Duboscq, 1903; Duffaut, 1908; Selbie, 1913; Takesita, 1918]. The first attempt to review and classify all previous published records was made by Balazuc \& Schubart [1962]. That study resulted in the definition of five principal structural types of centipede anomalies, namely: (1) helicomerism (spiral segmentation), (2) homeotic mutation (the mutation of one structure into another), (3) schistomely (the bifurcation of appendages), (4) symphysomely ("symphysomélies"; for instances of "fused" antennal or leg articles), and (5) atrophies of appendages (usually as the result of regeneration or injury on antennae or legs). Much later, Minelli \& Pasqual [1986] accepted only the first three types of anomalies from that classification. The last two types were presented as doubtfully representing teratology, with a high possibility that damage occurred due to regeneration during post-embryonic life. Lewis [1987] commented on such a reduced classification and indicated that all centipede malformations recorded could not be covered only by those three types. He claimed that certain cases could be due to some developmental problems (developmental abnormality) or a possible regeneration after damage, which cannot be explained in terms of such a classification. In several recent studies, the classification of the centipede anomalies recorded is mostly based on the delimitations by Minelli \& Pasqual [Leśniewska, 2012; Leśniewska, Barber, 2014; Leśniewska et al., 2009a, b].

In this study, we describe and analyse an anomaly on one ultimate leg in Cryptops parisi Brolemann, 1920. This is the first formal record of schistomely within the family Cryptopidae, and the second one reported for terminal legs in Chilopoda.

\section{Material and methods}

From March to November 2012, for the purpose of developmental studies we collected 1212 specimens representing the genus Cryptops Leach, 1814 at Izbice near Novi Pazar in southwestern Serbia, Balkan Peninsula (N 4307.333', E 22³4.354'; elevation about 700 $\mathrm{m}$ a.s.l.; under stones and in leaf litter in a mixed beech forest). Altogether, three Cryptops species were identified: C. anomalans Newport, 1844, C. hortensis (Donovan, 1810), and $C$. parisi. The last-mentioned species was dominant in the sample with a total of 956 specimens. One adult female of $C$. parisi (collected on August $18^{\text {th }}, 2012$ ) showed an unusual structure of the left ultimate leg. 

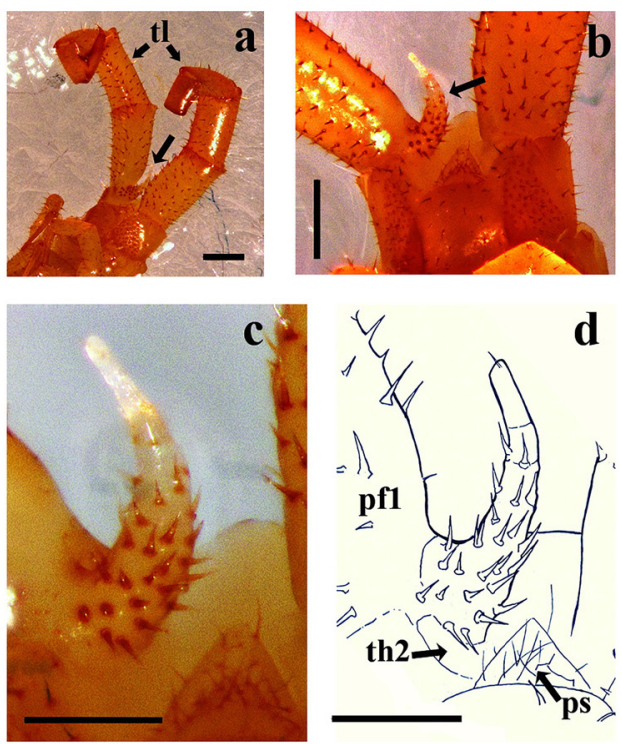

d
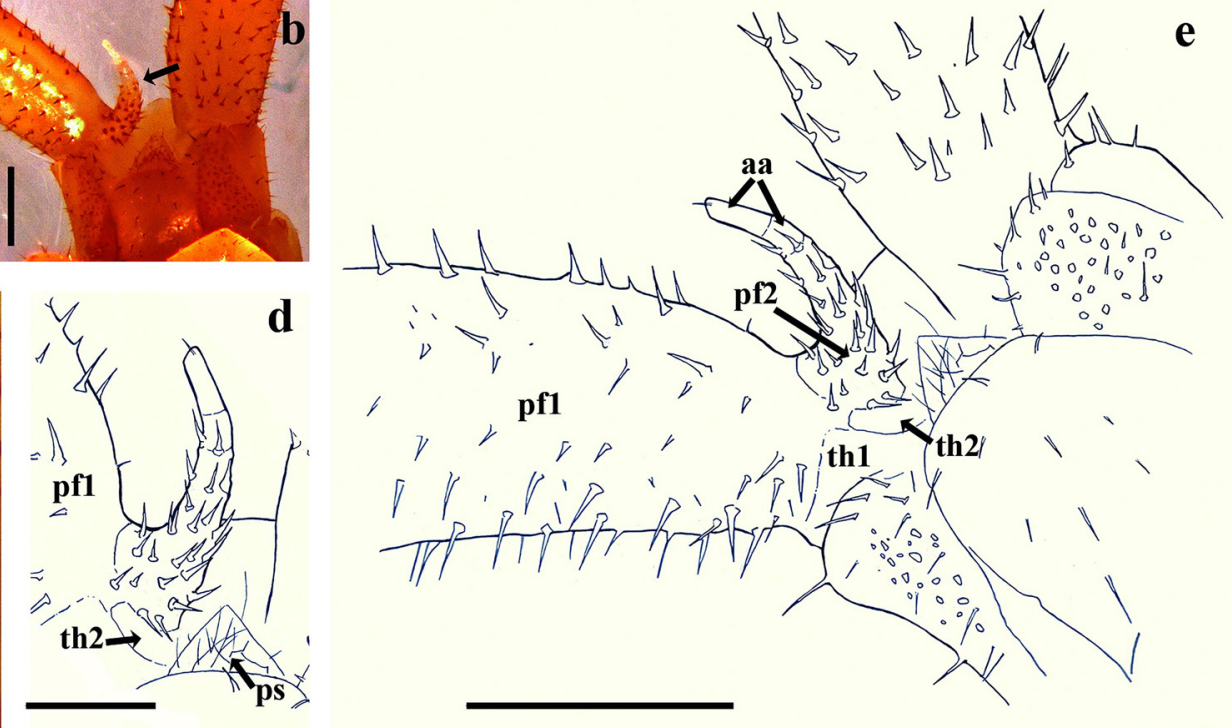

Figure. Schistomelic abnormality of a terminal leg of Cryptops parisi. Photographs of irregular structure (a-c). a - postpedal segments with terminal legs, ventral side; arrow shows the position of the abnormal structure. $\mathbf{b}$ - a closer look at the postpedal segments with abnormality; arrow shows the abnormal structure. c - enlarged view of the irregular leg. Drawings of abnormality (d and e). d enlarged view of abnormal structure. e — postpedal segment with abnormality, a closer look. Tags: aa — apical segments; pf1 — prefemur of regular left terminal leg; pf 2 — prefemur of irregular leg; ps — postpedal segments; th1 — trochanter of regular left terminal leg; th2 — trochanter of irregular leg; tl - terminal leg. Scale bars: a, b, and e: $0.5 \mathrm{~mm}$; c and d: $0.2 \mathrm{~mm}$.

Рисунок. Схистомелия последней ноги Cryptops parisi. Фотографии неправильной структуры (a-c). a - постпедальные сегменты с последними ногами, снизу; стрелка показывает положение уродливой структуры. b - увеличенные постпедальные сегменты с последними ногами; стрелка показывает уродливую структуру. с - увеличенная неправильная нога. Рисунки уродства (d и e). d - увеличенная уродливая структура. e - постпедальный сегмент с уродством, увеличено. Обозначения: аa вершинные членики; pf1 - предбедро обычной последней левой ноги; pf2 - предбедро неправильной последней левой ноги; ps постпедальные сегменты; th1 - вертлуг обычной последней левой ноги; th2 — вертлуг неправильной последней левой ноги; tl последняя нога. Масштаб: a, b и е: 0,5 мм; с и d: 0,2 мм.

This female is presently stored in a plastic tube, preserved in $70 \%$ ethanol, and deposited as specimen CPA372 in one of the collections of the Institute of Zoology, University of Belgrade - Faculty of Biology, Serbia. For species identification, recording the meristic and morphometric parameters, and taking the pictures, we used a Carl Zeiss Stemi 2000-C stereo microscope with a mounted digital camera and an integrated Axio Vs40 system in conjunction with the Carl Zeiss 4.8.2.0 software package. Species determination followed the diagnostic characters reported by Lewis [2011]. Determination of the sex was based on the external morphological characters of the postpedal segments described by Pichler [1987]. All terms used in the description are harmonized with the terminology proposed by Bonato et al. [2010]. For the purpose of a comparison with the previously published records indicating the same type of abnormality, we used the currently accepted species names listed in the ChiloBase electronic database [Bonato et al., 2016] and in the study of Bonato \& Minelli [2014].

\section{Results}

The unusual feature of the $C$. parisi female in question was not spotted directly in the field during the collection. That individual was captured from leaf litter, showed a behaviour normal for the given species, and lacked any indication of differences from other specimens collected at the same locality. A closer look under a stereo microscope revealed a four-segmented stump elongated from the base of the left terminal leg (Figs a-e). The specimen, except for the abnormal structure, was determined as an adult female with characteristics quite usual for the species.

The best way to picture this abnormal structure is to describe it as a miniature third terminal leg with a reduced number of segments. The bifurcation starts from the basal segment (coxa), which is held in common by regular legs and this irregular leg. The first unshared segment is the trochanter (Figs c-d). The following segment is the largest one, being expanded in the proximal part and narrowed distally. This article looks like the prefemur of a regular terminal leg, but is notably smaller in size and it displays a conspicuous setation with a striking colouration. The two remaining apical segments are white and poorly chitinized (Figs $\mathrm{a}-\mathrm{c})$. Those features probably indicate that the differentiation of this part is still not completed. The setation is sparse, with only 2-3 setae scattered along this part of the structure. 
If we exclude a slightly altered pattern of setation at the base of the prefemur of the left terminal leg, there are no visible differences between the terminal legs in this female (Figs $a-b, e)$. Measuring the approximate size shows a slightly longer left terminal leg $(4.56 \mathrm{~mm})$ compared to the right one $(4.51 \mathrm{~mm})$, but with a somewhat narrower base of the prefemur in the left one $(0.4$ $\mathrm{mm})$ than in the right one $(0.46 \mathrm{~mm})$. The length of the irregular structure is $0.73 \mathrm{~mm}$, and its width in the widest part is $0.19 \mathrm{~mm}$. The overall length of the specimen amounts to $19.66 \mathrm{~mm}$.

\section{Discussion}

From the oldest to recent records, there are only 23 schistomelic specimens of Chilopoda described in the literature (see Table). Eighteen of them are from the order Geophilomorpha (eight different species from a total of four families, namely, Dignathodontidae, Himantariidae, Linotaeniidae, and Schendylidae) [Léger, Duboscq, 1903; Duffaut, 1908; Minelli, Pasqual, 1986; Leśniewska, 2004, 2012; Iorio, 2005]; four specimens are from the order Scolopendromorpha (three species, all from the family Scolopendridae) [La Greca, 1955; Lewis, 1968; Vega-Román, Hugo-Ruiz, 2015]; and only one is from the order Lithobiomorpha (family Lithobiidae) [Demange, 1959]. No schistomelic abnormalities have been recorded in the orders Scutigeromorpha and Craterostigmomorpha. Schistomely in centipedes is usually present as a bifurcation of some trunk leg (in 19 cases). Significantly rarer are similar abnormalities of antennae, maxillipedes, gonopods or terminal legs (only one case per structure).

The above schistomely reported in $C$. parisi from Serbia represents only the second case of such an irregular structure of the terminal legs in centipedes. The previous case was reported by Lewis [1968] for one female from the Nigerian population of Scolopendra morsitans Linnaeus, 1758 (cited as S. amazonica Bücherl, 1946). That specimen had both regenerative ultimate legs, with bifurcation only on the left one. Apart from the fact that in both specimens the abnormal phenotype is expressed in females and on the left terminal legs, there are no other similarities between these two cases. In the Nigerian $S$. morsitans specimen, bifurcation occurred from a deformed femur. Starting from this segment, a central branch is extended into two articles and has a rounded apex; developed laterally there is a narrower appendix with a full number of segments. In the $C$. parisi specimen, the first bifurcated article is the trochanter. It is quite clear in both cases that the bifid terminal legs are obvious signs of a regenerative process, e.g., the result or repercussion of some disorder in regenerative mechanisms.

The origin of the bifurcation in the $C$. parisi specimen is somewhat harder to explain than in the previous case. There is no visible sign that this specimen had been damaged and regenerated. Both terminal legs have similar dimensions (Fig. a) and only a slightly de- ranged setation on the prefemur of the left leg (a smaller number of setae) (Fig. b). Other segments are quite symmetrical and show no differences between both legs. Based on this, the reappearance of appendages through a process of regeneration cannot be directly cited as the cause. In Cryptops species, the autonomy of ultimate legs followed by the appearance of new ones after the loss of a previous one is widely known and occurs very frequently. Lewis [2010] suggested a defensive role of terminal legs, resulting from a combination of their flexure with their appendotomy. The abandoned leg can impede a potential predator and provides time to escape. Incomplete autotomy (severing of only a part of the leg base) with activation of regenerative mechanisms in that region, which leads to the appearance of a new parallel appendage, can be a possible cause of the genesis of the described structure. In support of such a reconstruction, we can cite our field observations in collecting Cryptops specimens that incomplete autotomy was a quite common event.

The frequency of finding abnormal specimens is usually not high and depends on the type of abnormality, the number of collected animals, the characteristics of the population and the locality. In most cases, there is commonly only one reported specimen and authors often do not provide information about the size of the sample. In a large sample of Eupolybothrus transsylvanicus (Latzel, 1882), Mitić \& Makarov [2007] reported that abnormal individuals comprised a share of $0.71 \%$ (of a total of 1128 analysed specimens); Mitić et al. [2011] reported $0.003 \%$ abnormal individuals (of 362 examined specimens) of Clinopodes carinthiacus (Latzel, 1880) (after Bonato \& Minelli [2014]; cited as C. trebevicensis Verhoeff, 1898) and $0.002 \%$ abnormal individuals (of 512 specimens) of $C$. flavidus C.L. Koch, 1847; and Vega-Román \& Hugo-Ruiz [2015] recorded three abnormal individuals $(1.33 \%)$ of 400 analysed specimens of Akymnopellis chilensis (Gervais, 1847) and $A$. platei (Attems, 1903). A low percentage of abnormal individuals was also reported by Leśniewska et al. [2009a] for the species Geophilus alpinus Meinert, 1870 (two anomalous individuals, or $3.8 \%$ of 53 examined specimens); G. flavus (De Geer, 1778) (four anomalous individuals, or $2.3 \%$ of 178 examined specimens); and Schendyla nemorensis (C.L. Koch, 1837) (one anomalous individual, or $0.8 \%$ of 128 examined specimens).

Until now, the only exceptions from such a pattern were reports for the species Haplophilus subterraneus (Shaw, 1794), with an extremely high percentage of abnormal specimens in populations [Leśniewska, 2012; Leśniewska et al., 2009a, b]. Leśniewska [2012], in an analysis of 31 different European populations of this species, reported that a total of 26 populations had specimens with some morphological abnormality (896 individuals, or $31.4 \%$ of 2858 specimens examined). The reported percentages for some populations were even higher: $68.0 \%(n=50$; where $n$ is the number of analysed specimens) for the population near Lübeck, 
Table. Published records of centipede schistomely. Таблица. Опубликованные случаи схистомелии у губоногих.

\begin{tabular}{|c|c|c|c|c|}
\hline Order /Family & Species name & $\begin{array}{l}\text { Body } \\
\text { structure with } \\
\text { expressed } \\
\text { anomaly } \\
\end{array}$ & $\begin{array}{l}\text { No. of } \\
\text { specimens } \\
\text { with abnormal } \\
\text { phenotypes } \\
\end{array}$ & Reference \\
\hline \multicolumn{5}{|l|}{ Lithobiomorpha } \\
\hline Lithobiidae & $\begin{array}{l}\text { Lithobius borealis } \\
\text { Meinert, } 1868\end{array}$ & gonopods & 1 & Demange, 1959 \\
\hline \multicolumn{5}{|c|}{ Scolopendromorpha } \\
\hline \multirow{3}{*}{$\begin{array}{l}\text { Scolopen- } \\
\text { dridae }\end{array}$} & $\begin{array}{l}\text { Akymnopellis chilensis } \\
\text { (Gervais, 1847) }\end{array}$ & trunk leg & 2 & $\begin{array}{l}\text { Vega-Román, Hugo-Ruiz, } \\
2015\end{array}$ \\
\hline & $\begin{array}{l}\text { Scolopendra morsitans } \\
\text { Linnaeus, } 1758\end{array}$ & terminal leg & 1 & $\begin{array}{l}\text { Lewis, } 1968 \text { (as } S \text {. } \\
\text { amazonica (Bücherl, } \\
\text { 1946)) }\end{array}$ \\
\hline & Scolopendra sp. & forcipule & 1 & La Greca, 1955 \\
\hline \multicolumn{5}{|c|}{ Geophilomorpha } \\
\hline \multirow{3}{*}{$\begin{array}{l}\text { Dignathodon- } \\
\text { tidae }\end{array}$} & $\begin{array}{l}\text { Henia bicarinata } \\
\text { (Meinert, 1870) }\end{array}$ & trunk leg & 1 & Minelli, Pasqual, 1986 \\
\hline & $\begin{array}{l}\text { Henia illyrica (Meinert, } \\
1870 \text { ) }\end{array}$ & trunk leg & 1 & Minelli, Pasqual, 1986 \\
\hline & $\begin{array}{l}\text { Henia vesuviana } \\
\text { (Newport, 1845) }\end{array}$ & trunk leg & 1 & $\begin{array}{l}\text { Duffaut, } 1908 \text { (as } \\
\text { Chaetechelyne } v \text {. } \\
\text { Newport, 1845) }\end{array}$ \\
\hline \multirow{3}{*}{ Himantariidae } & $\begin{array}{l}\text { Haplophilus } \\
\text { subterraneus (Shaw, } \\
1794 \text { ) }\end{array}$ & antenna & 1 & $\begin{array}{l}\text { Leśniewska, } 2004 \text { (as } \\
\text { Stigmatogaster s. (Shaw, } \\
1794) \text { ) }\end{array}$ \\
\hline & $\begin{array}{l}\text { Haplophilus } \\
\text { subterraneus (Shaw, } \\
1794)\end{array}$ & trunk legs & 10 & Leśniewska, 2012 \\
\hline & $\begin{array}{l}\text { Himantarium gabrielis } \\
\text { (Linnaeus, 1767) }\end{array}$ & trunk leg & 1 & Minelli, Pasqual, 1986 \\
\hline Linotaeniidae & $\begin{array}{l}\text { Strigamia acuminata } \\
\text { (Leach, 1815) }\end{array}$ & trunk leg & 1 & Minelli, Pasqual, 1986 \\
\hline \multirow{2}{*}{ Schendylidae } & $\begin{array}{l}\text { Schendyla nemorensis } \\
\text { (C.L. Koch, 1837) }\end{array}$ & trunk leg & 1 & Iorio, 2005 \\
\hline & $\begin{array}{l}\text { Schendyla vizzavone } \\
\text { Léger et Duboscq, } 1903\end{array}$ & trunk leg & 1 & Léger, Duboscq, 1903 \\
\hline
\end{tabular}

Germany; $51.2 \%(\mathrm{n}=41)$ for the population from Koblenz, Germany; $40.6 \%(\mathrm{n}=32)$ for the population from Quimper, France; $37.1 \%(\mathrm{n}=35)$ for the population from near Seilhac, France; $25.5 \%(n=809)$ for the population from Poznań, Poland; etc. A high frequency of abnormal specimens $(50 \%)$ was also reported for the species $H$. souletinus (Brölemann, 1907), but using only a small number of examined individuals (14) [Leśniewska, Barber, 2014].

In comparison with such high percentages of abnormality for those populations, our case is one with an extremely low frequency. We here report only a single anomalous individual from among 956 specimens examined, i.e., some $0.105 \%$. Other types of morphological anomalies from this population were not considered, and that is a pivotal reason for such a low frequency. Our opinion is that the described anomaly does not affect the fitness of specimens, since its dorsal position relative to the postpedal segments provides enough space for contact of the genital segment with the spermatophore (indirect sperm transfer). Also, to judge from the condition of setation, it seems that this structure remained after the last moulting. Notwithstanding the assertion of Leśniewska [2012] that naturally occurring morphological anomalies in centipedes are common events, it is clear that some types of anomaly are quite rare. The case reported here on C.parisi is such an infrequent type of anomaly.

Acknowledgements. This study was supported by the Serbian Ministry of Education, Science, and Technology (Grant 173038). We wish to thank Igor Stojanović for providing us with drawings of the anomaly and Ivan Apostolski for his assistance in processing different parts of the figure. 
We are most grateful to Sergei I. Golovatch for his suggestions to improve the manuscript. The authors are highly obliged to Mr. Raymond Dooley for correcting the English of the manuscript.

\section{References}

Balazuc J., Schubart O. 1962. La teratologie des myriapodes // Année Biologique. Vol.1. Fasc.3-4. P.145-174.

Bonato L., Chagas Junior A., Edgecombe G.D., Lewis J.G.E., Minelli A., Pereira L.A., Shelley R.M., Stoev P., Zapparoli M. 2016. ChiloBase 2.0 - A World Catalogue of Centipedes (Chilopoda). Available at: http://chilobase.biologia.unipd.it

Bonato L., Edgecombe G.D., Lewis J.G.E., Minelli A., Pereira L.A., Shelley R.M., Zapparoli M. 2010. A common terminology for the external anatomy of centipedes (Chilopoda) // ZooKeys. Vol.69. P.17-51.

Bonato L., Minelli A. 2014. Chilopoda Geophilomorpha of Europe: a revised list of species, with taxonomic and nomenclatorial notes // Zootaxa. Vol.3770. P.1-136.

Brölemann H.W. 1894. Difformité constatée chez un Himantarium gabrielis L. // Feuille des Jeunes Naturalistes. Sér.3. Vol.24. No. 284. P.124-125.

Brölemann H.W. 1904. Chilopodes monégasques // Bulletin du Musée Oceánographique de Monaco. No.15. P.1-15.

Demange J.M. 1959. Myriapodes Chilopodes de Madère (Mission de M. le Pr. A. Vandel) // Revue française d'Entomologie. Vol.26. P.157-166.

Duffaut M. 1908. Description de quelques difformités observés chez des articulés // Sociéte d'Histoire Naturelle et des Sciences Biologiques et Énergétiques de Toulouse. Vol.41. P.54-56.

Gadeau de Kerville H. 1898. Recherches sur les faunes marine et maritime de la Normandie. 2ème voyage: région de Grandcamp les Bains (Calvados) et Iles Saint Marcouf (Manche). Juillet-Septembre 1894. // Bulletin de la Societé des Amis des Sciences Naturelles de Rouen. Vol.33. P.309-422.

Hutton F.W. 1878. Notes on the New Zealand Myriapoda in the Otago Museum // Transactions and Proceedings of the New Zealand Institute. Vol.10. P.288-293.

Iorio E. 2005. Un cas tératologique observé chez Schendyla nemorensis (C. L. Koch, 1837) (Chilopoda, Geophilomorpha, Schendylidae) // Le Bulletin d'Arthropoda. Vol.24. P.51-53.

La Greca M. 1955. Su una malformazione delle forcipule di un Chilopodo del gen. Scolopendra // Bollettino della Società dei Naturalisti in Napoli. Vol.64. P.23-27.

Léger L., Duboscq O. 1903. Sur les Myriapodes de Corse el leurs parasites // Archives de Zoologie Expérimentale et Générale. T.1. P.307-358.

Leśniewska M. 2004. Bifurcation of one antenna in Stigmatogaster subterraneus (Shaw, 1794) (Chilopoda: Geophilomorpha) // Biology Letters. Vol.41. No.1. P.51-53.
Leśniewska M. 2012. Morphological anomalies in Haplophilus subterraneus (Shaw, 1794) (Chilopoda: Geophilomorpha). Poznań: Wydawnictwo Kontekst. 207 p.

Leśniewska M., Barber A.D. 2014. Abnormalities in a British population of Haplophilus souletinus (Brölemann, 1907) // Bulletin of the British Myriapod \& Isopod Group. Vol.27. P.38-40.

Leśniewska M., Bonato L., Fusco G. 2009a. Morphological anomalies in a Polish population of Stigmatogaster subterranea (Chilopoda: Geophilomorpha): a multi-year survey // Soil Organisms. Vol.81. No.3. P.347-358.

Leśniewska M., Bonato L., Minelli A., Fusco G. 2009b. Trunk anomalies in the centipede Stigmatogaster subterranea provide insight into late-embryonic segmentation // Arthropod Structure \& Development. Vol.38. P.417-426.

Lewis J.G.E. 1968. Individual variation in a population of the centipede Scolopendra amazonica from Nigeria and its implications for methods of taxonomic discrimination in the Scolopendridae // Journal of the Linnean Society of London, Zoology. Vol.47. No.312. P.185-207.

Lewis J.G.E. 1987. On some structural abnormalities in Lithobius and Cryptops (Chilopoda) and their possible significance // Bulletin of the British Myriapod Group. Vol.4. P.3-6.

Lewis J.G.E. 2010. On the function of the ultimate legs of Cryptops and Theatops (Chilopoda, Scolopendromorpha) // International Journal of Myriapodology. Vol.3. P.145-151.

Lewis J.G.E. 2011. A review of the species in the genus Cryptops Leach, 1815 from the Old World related to Cryptops (Cryptops) hortensis (Donovan, 1810) (Chilopoda, Scolopendromorpha) // International Journal of Myriapodology. Vol.4. P.11-50.

Minelli A., Pasqual C. 1986. On some abnormal specimens of centipedes (Chilopoda) // Lavori della Società Veneziana di Scienze Naturali. Vol.11. P.135-141.

Mitić B.M., Makarov S.E. 2007. On some morphological anomalies in Eupolybothrus transsylvanicus (Latzel, 1882) (Chilopoda: Lithobiomorpha)// Archives of Biological Sciences. Vol.59. No.1. P.3-4.

Mitić B.M., Makarov S.E., Ilić B.S., Stojanović D.Z., Ćurčić B.P.M. 2011. Cases of trunk segmental anomalies in the geophilomorph centipedes Clinopodes flavidus C. L. Koch and Clinopodes trebevicensis (Verhoeff) (Chilopoda: Geophilomorpha) // Archives of Biological Sciences. Vol.63. No.3. P.841-845.

Pichler H. 1987. Neue Nachwerse von Cryptops-Arten in Nordtirol und anderen Bundesländern Österreichs (Chilopoda, Scolopendromorpha, Cryptopidae) // Berichte des Naturwissenschaflich-Medizinischen Vereins in Innsbruck. Bd.74. S.125-139.

Selbie C.M. 1913. A new variety of Polydesmus coriaceus, Porat, and note on a centipede monstrosity // Annals and Magazine of Natural History. Ser.8. Vol.12. P.439-443.

Takesita M. 1918. A centipede with an abnormal antenna // Annotationes Zoologicae Japonenses. Vol.9. No.4. P.389-391.

Vega-Román E., Hugo-Ruiz V. 2015. Tres casos teratológicos en miriápodos chilenos // Revista Colombiana de Entomologia. Vol.41. No.1. P.153-155.

Responsible editor S.I. Golovatch 